\title{
Screening of traditional European herbal medicines for acetylcholinesterase and butyrylcholinesterase inhibitory activity
}

\author{
NATALIA WSZELAKI ${ }^{1, *}$ \\ AGNIESZKA KUCIUN ${ }^{2}$ \\ ANNA KAROLINA KISS 2 \\ ${ }^{1}$ Institute of Pharmacy \\ Free University of Berlin \\ D-14195 Berlin, Germany \\ ${ }^{2}$ Department of Pharmacognosy \\ and Molecular Basis of Phytotherapy \\ Faculty of Pharmacy \\ Medical University of Warsaw \\ 02-098 Warsaw, Poland
}

\begin{abstract}
Acetylcholinesterase (AChE) inhibitors are widely used for the symptomatic treatment of Alzheimer's disease (AD) to enhance central cholinergic transmission. On the other hand, butyrylcholinesterase (BuChE) inhibitors were reported to produce a significant increase in brain extracellular AChE without triggering severe peripheral or central side effects. In the present study, we selected twelve plants used in traditional European medicine to treat different central nervous system (CNS) disorders or to improve memory.

Methanolic and hexane extracts of these plants were tested for the AChE and BuChE inhibitory activity using Ellman's colorimetric method. The most potent AChE and BuChE inhibition was observed in the hexane extracts of the flowers of Arnica chamissonis Less. subs. foliosa and Ruta graveolens L. herb at a concentration of $400 \mu \mathrm{g} \mathrm{mL}^{-1}$. However, methanolic extracts of the flowers of Arnica chamissonis Less. subs. foliosa and the Hypericum perforatum L. herb demonstrated at the same concentration, selective inhibition only against $\mathrm{AChE}$ but not against BuChE. The other extracts did not show any significant AChE or BuChE inhibitory activity. Our results show that further investigations of the extracts of arnica, rue and St. John's Wort are needed to identity the compounds responsible for the AChE and BuChE inhibitory activity.

Keywords: acetylcholinesterase inhibition, butyrylcholinesterase inhibition, traditional medicine
\end{abstract}

Alzheimer's disease (AD) is one of the most widespread neurodegenerative diseases that involve dementia and mainly afflict people over 65 years of age. The therapy of early and moderate stages of $\mathrm{AD}$ is mainly based on acetylcholine esterase inhibitors such as synthetic donepezil and galanthamine isolated from the bulbs of daffodils. However, these licensed medicines have drawbacks of inducing severe peripheral and central

\footnotetext{
* Correspondence; e-mail: natala345@yahoo.co.uk
} 
side effects, including gastrointestinal disturbances, insomnia, fatigue or depression. On the other hand, since the BuChE activity in AD increases progressively as the severity of dementia progresses, researchers have investigated selective BuChE inhibitors in the treatment of AD as well (1). The serious side effects caused by licensed drugs used to treat $\mathrm{AD}$ have forced researchers to investigate safer AChE- or BuChE inhibitors from natural sources.

One of the best sources of new substances to treat AD are natural products and their derivatives. Traditionally, plants have been used to enhance memory and to alleviate other symptoms associated with AD (2). The biologically active plant-derived substances that may be considered as a source of new anticholinesterase drugs come from different classes of compounds and are characterized by the diversity of their structures. The majority of bioactive substances are indole-, steroidal-, piperidine- and Amaryllidaceae alkaloids, phenylpropanoids (furanocoumarins, xantones, and flavonoids) and terpenoids (diterpenes) (2).

The aim of this study was to investigate possible AChE or BuChE inhibitors in plants traditionally used in European medicine and to point to the role of these plants as potential sources for the development of therapeutic agents of AD. Selection of the species screened in this study was based on their use as remedies for the central nervous system diseases, as antidotes for plant and animal poisoning or to enhance memory.

\section{EXPERIMENTAL}

\section{Plant material and chemicals}

Plants were collected from The Botanical Garden of the Polish Academy of Science. A specimen of each raw material is available in the herb collection of the Department of Pharmacognosy and Molecular Basis of Phytotherapy, Faculty of Pharmacy, Medical University of Warsaw, Poland. Each plant material was dried and ground in a grinder. Plants and their parts used in this study are presented in Table I.

Electric eel AChE (type VI-S), horse-serum BuChE, acetylthiocholine iodide, butyrylthiocholine chloride, 5,5'-dithio-bis[2-nitrobenzoic acid], Tris-HCl [Tris(hydroxymethyl)aminomethane hydrochloride], 1-naphtyl acetate, bovine serum albumin (BSA, albumin fraction $\mathrm{V}$ from bovine serum), 3,3'-dimethoxybiphenyl-4,4'-di(diazonium) zinc chloride (Fast Blue B salt), physostigmine salicylate, galanthamine hydrobromide, anisaldehyde were purchased from Sigma-Aldrich (USA). Methanol, toluene, ethyl acetate, hexane and sulphuric acid were purchased from Chempur (Poland). All reagents used in the study were of analytical grade.

\section{Extract preparation}

For extraction, $2 \mathrm{~g}$ of air-dried and powdered plant material was extracted over a water bath at $60{ }^{\circ} \mathrm{C}$ in $40 \mathrm{~mL}$ of methanol or hexane under reflux for $30 \mathrm{~min}$. The extraction was done in triplicate. The resulting liquid extract was filtered and concentrated to dryness under reduced pressure at $60^{\circ} \mathrm{C}$. At $60^{\circ} \mathrm{C}$, the components in plant extracts were 
N. Wszelaki et al:: Screening of traditional European herbal medicines for acetylcholinesterase and butyrylcholinesterase inhibitory activity, Acta Pharm. 60 (2010) 119-128.

stable. The dry extracts were stored at $4{ }^{\circ} \mathrm{C}$ and dissolved in an appropriate solvent just before the test.

\section{Determination of enzyme activity}

All extracts were tested for AChE and BuChE inhibitory activity at concentrations of 100 and $400 \mu \mathrm{g} \mathrm{mL}^{-1}$ by the modified spectrophotometric method developed by Ellman (3). For herbal extracts that were proven to exert significant inhibition and for positive controls, dose-dependent inhibitory assays were performed. The plant extracts were tested in a concentration range of 12.5 to $400 \mu \mathrm{g} \mathrm{mL}^{-1}$. Galanthamine hydrobromide and physostigmine salicylate were used as $\mathrm{AChE}$ and $\mathrm{BuChE}$ positive controls. They were tested in a concentration range between 0.01 and $100 \mu \mathrm{g} \mathrm{mL}^{-1}$.

The assay was performed in a 1.5-mL Eppendorf tube as follows: $1 \mathrm{mg}$ of methanolic extract was dissolved in $1 \mathrm{~mL}$ Tris- $\mathrm{HCl}$ (50 mmol L-1, $\mathrm{pH} 7.8)$. Hexane extract $(1 \mathrm{mg})$ was dissolved in $100 \mu \mathrm{L}$ methanol and diluted to $1 \mathrm{~mL}$ with Tris- $\mathrm{HCl}(50 \mathrm{mmol} \mathrm{L}-1, \mathrm{pH}$ 7.8). Positive controls, namely galanthamine and physostigmine, were dissolved in methanol (1 $\left.\mathrm{mg} \mathrm{mL}^{-1}\right)$.

To determine the $\mathrm{AChE}$ and BuChE inhibitory activity, the following reaction was performed. An appropriate amount of extract or positive control and $40 \mu \mathrm{L}$ of AChE $\left(0.45 \mathrm{U} \mathrm{mL}^{-1}\right)$ or BuChE $\left(0.45 \mathrm{U} \mathrm{mL}^{-1}\right)$ was mixed and diluted to $1 \mathrm{~mL}$ with Tris-HCl. After $30 \mathrm{~min}$ of incubation at $4{ }^{\circ} \mathrm{C}$, the reaction was initiated by addition of $20 \mu \mathrm{L}$ of 5,5'-dithio-bis[2-nitrobenzoic acid] $\left(3 \mathrm{mmol} \mathrm{L}^{-1}\right)$ and $20 \mu \mathrm{L}$ of acetylthiocholine iodide or butyrylthiocholine chloride, respectively (both $15 \mathrm{mmol} \mathrm{L}^{-1}$, dissolved in Tris- $\mathrm{HCl}$ ). The samples were incubated for another $20 \mathrm{~min}$ over a water bath at $37^{\circ} \mathrm{C}$ and the reactivity was terminated by addition of $20 \mu \mathrm{L}$ physostigmine salicylate $\left(0.1 \mathrm{mmol} \mathrm{L}^{-1}\right.$ in methanol). Absorbance of the produced yellow 5-thio-2-nitrobenzoate anion was measured at a wavelength of $412 \mathrm{~nm}$ using a Shimadzu UV 160A (Japan) spectrophotometer. Tris- $\mathrm{HCl}$ buffer was used as a blank.

\section{Thin layer chromatography (TLC) bioautographic assay}

TLC bioautographic assay was performed as described by Marston et al. (4). Extract of the Arnica chamissonis flowers, $20 \mu \mathrm{L}(0.2 \mathrm{~g}$ of dried extract dissolved in $1 \mathrm{~mL}$ methanol) was applied to a silica gel plate (Kieselgel G, F254, type 60, Merck, Germany) and eluted with toluene/ethyl acetate $(50: 50, V / V)$. After drying, the plate was sprayed with $13 \mathrm{U} \mathrm{mL}^{-1} \mathrm{AChE}$ (dissolved in $50 \mathrm{mmol}^{-1}$ Tris- $\mathrm{HCl}$ with $0.1 \% \mathrm{BSA}, \mathrm{pH} 7.8$ ) and kept in a water bath at $37{ }^{\circ} \mathrm{C}$ for 20 minutes. The chromatogram was dried until complete mobile phase was removed. Finally, the plate was sprayed with $0.25 \%$ 1-naphtyl acetate (dissolved in methanol) and $0.25 \%$ Fast Blue B salt (dissolved in deionized water). After a few minutes, a purple background appeared with white spots for AChE inhibiting compounds.

\section{TLC method}

Methanolic and hexane extracts of Arnica chamissonis ssp. foliosa, $10 \mu \mathrm{L}$ and $20 \mu \mathrm{L}$, respectively ( $0.2 \mathrm{~g}$ of dried extract dissolved in $1 \mathrm{of}$ solvent) were applied to the silica gel 
N. Wszelaki et al:: Screening of traditional European herbal medicines for acetylcholinesterase and butyrylcholinesterase inhibitory activity, Acta Pharm. 60 (2010) 119-128.

plate (Kieselgel G, F254, type 60, Merck) and eluted with toluene/ethyl acetate (50:50, $V / V)$. Visualization of sesquiterpene lactones was done by spraying with methanolic solutions of $0.5 \%$ anisaldehyde and $5 \%$ sulphuric acid followed by heating at $105{ }^{\circ} \mathrm{C}$ for 5 minutes.

\section{Date processing}

The extent of the enzymatic reaction was calculated based on the following equation: $E=100-\left[\left(T-C_{1} / C_{0}\right) \times 100\right]$, where $E$ is the activity of the enzyme. $E$ value conveys the effect of the plant extract or the positive control on AChE or BuChE enzyme activity expressed as the percentage of the remaining activity in the presence of plant extract or positive control, $T$ (test) is the absorbance of the tested sample (plant extract or positive control in the solvent) in the presence of enzyme, $C_{1}$ (control 1 ) is the absorbance of the tested sample (plant extract or positive control in the solvent) in the absence of enzyme, $C_{0}$ (control 0 ) is the absorbance of the solvent in the presence of enzyme.

Data are expressed as mean \pm standard error (SEM) and the results were taken from at least three independent experiments performed in duplicate.

\section{Estimation of $\mathrm{IC}_{50}$ values}

The $I C_{50}$ values (concentration of test compounds that inhibits the hydrolysis of substrates by $50 \%$ ) were determined by spectrophotometric measurement of the effect of increasing concentrations of test compounds (plant extracts and positive controls) on the $\mathrm{AChE}$ or BuChE activity. $I C_{50}$ values were obtained from dose-effect curves by linear regression.

\section{RESULTS AND DISCUSSION}

Screening of methanolic and hexane extracts showed that 4 out of 24 plant extracts were able to inhibit the enzymatic activity of either AChE or BuChE or both. It was found out that all the hexane and methanolic extracts had dose-dependent inhibitory activity. Significant reduction in the activity of AChE was observed at the concentration of $400 \mu \mathrm{g} \mathrm{mL}^{-1}$ for Arnicae flos (hexane and methanolic extract), Rutae herba (hexane and methanolic extract) and Hyperici herba (methanolic extract). The strongest BuChE inhibitors that showed inhibition higher than $50 \%$ at the concentration of $100 \mu \mathrm{g} \mathrm{mL}^{-1}$ were found in hexane extracts of Rutae herba and Arnicae flos. The results on the effects of the tested herbal extracts on AChE and BuChE activity are summarized in Table I. The dose-dependent AChE inhibitory activity of these three herbs was further studied and the $I C_{50}$ values of inhibition are tabulated in Table II.

The most potent extract was the hexane extract of Arnica chamissonis with $I C_{50}$ of $29 \mu \mathrm{g} \mathrm{mL}-1$. At a concentration of $100 \mu \mathrm{g} \mathrm{mL}-1$, it reduced the enzymatic activity of AChE to $23.6 \%$ and BuChE to $36.1 \%$. Methanolic extract of Arnica chamissonis caused similar reduction of AChE activity at a concentration of $100 \mu \mathrm{g} \mathrm{mL}^{-1}\left(I_{50}=43 \mu \mathrm{g} \mathrm{mL}^{-1}\right)$. However, no BuChE inhibitory activity was found for the hexane extract of Arnica chamissonis. The AChE inhibitory effect of these extracts was less potent than that of the refer- 
N. Wszelaki et al.: Screening of traditional European herbal medicines for acetylcholinesterase and butyrylcholinesterase inhibitory activity, Acta Pharm. 60 (2010) 119-128.

Table II. Anti-AChE and BuChE activity of the most active plant extracts

\begin{tabular}{lcc}
\hline \multicolumn{1}{c}{ Sample } & $I C_{50}(\mathrm{AchE})\left(\mu \mathrm{g} \mathrm{mL} \mathrm{m}^{-1}\right)$ & $I C_{50}(\mathrm{BuChE})\left(\mu \mathrm{g} \mathrm{mL}^{-1}\right)$ \\
\hline Arnicae flos (hexane extract) & 29 & 88 \\
Arnicae flos (methanolic extract) & 43 & - \\
Hyperici herba (methanolic extract) & 178 & - \\
Rutae herba (hexane extract) & 34 & 61 \\
Positive control & $I C_{50}(\operatorname{anti-AchE})$ & $I C_{50}(\mathrm{anti}-\mathrm{BuChE})$ \\
Galanthamine & $0.14 \mu \mathrm{g} \mathrm{mL}^{-1}$ & $0.54 \mu \mathrm{g} \mathrm{mL}^{-1}$ \\
& $\left(0.37 \mu \mathrm{mol} \mathrm{L}^{-1}\right)$ & $\left(8.29 \mu \mathrm{mol} \mathrm{L}^{-1}\right)$ \\
Physostigmine & $0.064 \mu \mathrm{g} \mathrm{mL}^{-1}$ & $3.13 \mu \mathrm{g} \mathrm{mL}^{-1}$ \\
& $\left(0.21 \mu \mathrm{mol} \mathrm{L}^{-1}\right)$ & $\left(1.73 \mu \mathrm{mol} \mathrm{L}^{-1}\right)$ \\
\hline
\end{tabular}

- Not evaluated.

$I C_{50}$ values were obtained from the dose-effect curves by linear regression.

ences galanthamine (IC 50 of galanthamine for $\mathrm{AChE}$ and BuChE was 0.14 and $3.13 \mu \mathrm{g} \mathrm{L}^{-1}$, respectively) and physostigmine ( $I C_{50}$ of physostygmine for $\mathrm{AChE}$ and $\mathrm{BuChE} 0.064$ and $0.54 \mu \mathrm{g} \mathrm{L}^{-1}$, respectively).

The components found in Arnica chamissonis include sesquiterpene lactones, flavonoids and essential oil with terpenes. Detailed chemical composition of the tested plant parts is presented in Table III. Out of these compounds, terpenes like cineol, borneol, geraniol, 3-carene, $\alpha$-caryophyllene or limonene were previously found to express some $\mathrm{AChE}$ or BuChE inhibitory activity $(2,5)$. However, no sesquiterpene lactones inhibitory

a)

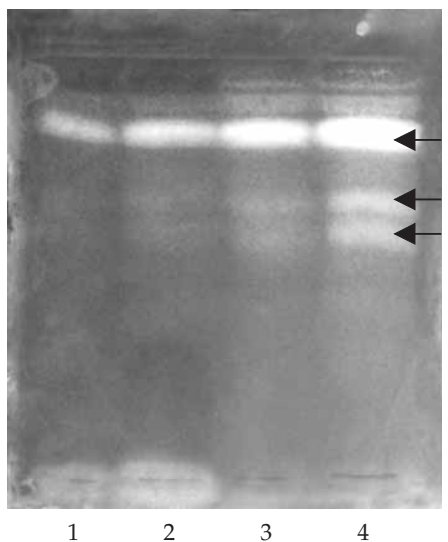

b)

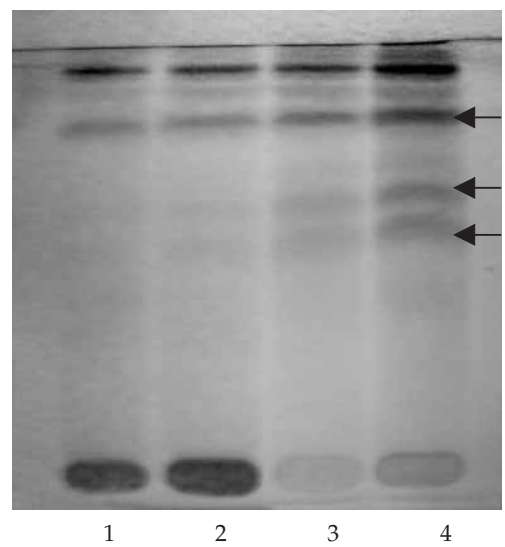

Fig. 1. TLC of extracts of Arnica chamissonis Less. ssp. foliosa showing acetylcholinesterase inhibitory activity: a) white spots indicate inhibition, arrows indicate the AChE inhibiting constituents, b) TLC plate sprayed with methanolic solution of $0.5 \%$ anisaldehyde and of $5 \%$ sulphuric acid followed by heating at $105{ }^{\circ} \mathrm{C}$ for 5 minutes. Black spots indicate the presence of sesquiterpene lactones; arrows indicate the $\mathrm{AChE}$ inhibiting constituents. 1-4 are methanolic extract $10 \mu \mathrm{L}$, methanolic extract $20 \mu \mathrm{L}$, hexane extract $10 \mu \mathrm{L}$, hexane extract $20 \mu \mathrm{L}$, respectively. 
N. Wszelaki et al:: Screening of traditional European herbal medicines for acetylcholinesterase and butyrylcholinesterase inhibitory activity, Acta Pharm. 60 (2010) 119-128.

Table III. Detailed chemical composition of the tested plants (literature survey)

\begin{tabular}{|c|c|c|c|}
\hline Plant species & Plant part & Chemical composition & References \\
\hline $\begin{array}{l}\text { Anchusa } \\
\text { officinalis L. }\end{array}$ & herb & $\begin{array}{l}\text { pyrrolizidine alkaloids, triterpene saponins, } \\
\text { polyphenolic acids }\end{array}$ & 10 \\
\hline $\begin{array}{l}\text { Arnica } \\
\text { chamissonis } \\
\text { Less. ssp. } \\
\text { Foliosa (Nutt.) } \\
\text { Maguire }\end{array}$ & flower & $\begin{array}{l}\text { sesquiterpene lactones of pseudoguaianolide type } \\
(0.2-1.5 \%) \text {-helenelin, flavonoids }(0.4-0.6 \%) \text {-flavonols } \\
\text { and flavones, essential oil }(0.15-0.28 \%) \text {-fatty acids, } \\
\text { sesquiterpenes, monoterpenes, caffeoylquinic acids- } \\
\text {-chlorogenic acid, cynarin, polysacharides }\end{array}$ & 11,13 \\
\hline $\begin{array}{l}\text { Ballota } \\
\text { nigra L. }\end{array}$ & herb & $\begin{array}{l}\text { phenylpropanoids ( } 5.5 \%) \text {-verbascoside, forsythoside B, } \\
\text { arenarioside and ballotetroside, diterpenoids, } \\
\text { flavonoids luteolin 7-lactate, } 7 \text {-glucosyllactate }\end{array}$ & 11 \\
\hline $\begin{array}{l}\text { Cnicus } \\
\text { benedictus L. }\end{array}$ & herb & $\begin{array}{l}\text { bitter sesquiterpene lactone ester cnicin }(0.2-0.7 \%) \text {; } \\
\text { other germacrane sesquiterpenes include salonitenolide } \\
\text { and artemisiifolin; the bitter lignans trachelogenin, } \\
\text { arctigenin, and nortracheloside are also present, essen- } \\
\text { tial oil }(0.03 \%)\end{array}$ & 12 \\
\hline $\begin{array}{l}\text { Galium } \\
\text { odoratum L. } \\
\text { Scop. }\end{array}$ & herb & $\begin{array}{l}\text { coumarins }(1.06 \%) \text {-coumarin, } o \text {-coumaric acid } \\
\text { glucoside; iridoids asperulosiode }(0.28 \%) \text {, } \\
\text { monotropein }(0.042 \%) \text {, scandoside }(0.042 \%)\end{array}$ & 13 \\
\hline $\begin{array}{l}\text { Hypericum } \\
\text { perforatum } \mathrm{L} .\end{array}$ & herb & $\begin{array}{l}\text { phloroglucinol derivatives }(0.2-0.4 \%) \text {, principally } \\
\text { hyperforin, adhyperforin, naphtodiantrones } \\
(0.1-0.3 \%) \text {-hypericin }(0.08 \%) \text {, pseudohypericin, } \\
\text { flavonoids }(2-4 \%) \text { include hyperoside, rutin, } \\
\text { isoquercitrin, biflavones and others, tannins- } \\
\text {-procyanidins, xanthones, essential oil }\end{array}$ & 11,12 \\
\hline $\begin{array}{l}\text { Hyssopus } \\
\text { officinalis L. }\end{array}$ & herb & $\begin{array}{l}\text { essential oil (0.3-1 \%)-mainly isopinocamphone, } \\
\text { limonene, b-pinene; flavonoids (5-6\%)-principally } \\
\text { diosmin (3-6\%), tanins ( } 5-8 \%) \text {, phenylpropanoids } \\
\text { including rosmarinic acid, caffeic acid and } \\
\text { isoferulyl-D-glucose ester, triterpenes-ursolic acid }\end{array}$ & 11,13 \\
\hline $\begin{array}{l}\text { Menyanthes } \\
\text { trifoliata L. }\end{array}$ & leaf & $\begin{array}{l}\text { secoiridoid glycosides dihydrofoliamenthin, } \\
\text { menthiafolin and loganin, monoterpenoid alkaloids } \\
(0.035 \%) \text { gentianine and gentianidine, gentialutein, } \\
\text { gentiatibetin, flavonoids }\end{array}$ & 12 \\
\hline $\begin{array}{l}\text { Primula offici- } \\
\text { nalis (L.) Hill. }\end{array}$ & flower & $\begin{array}{l}\text { saponins ( } 2 \%) \text {, flavonoids }(3 \%) \text {, carotinoids, } \\
\text { essential oil }\end{array}$ & 12 \\
\hline $\begin{array}{l}\text { Ruta } \\
\text { graveolens L. }\end{array}$ & herb & $\begin{array}{l}\text { essential oil (0.2-0.4\%) with nonan-2-one, flavonoids } \\
(2-5 \%) \text { - rutine, coumarins-furanocoumarines - } \\
\text { bergapten, psoralen, xanthoxanthin, xanthotoxin, } \\
\text { isopimpinellin and rutamarin, alkaloids }(0.4-1.4 \%) \text { are } \\
\text { furoquinoline alkaloids gamma-fagarine, skimmianine } \\
\text { and acridone alkaloids-arborinine }\end{array}$ & 14 \\
\hline $\begin{array}{l}\text { Tanacetum } \\
\text { parthenium (L.) } \\
\text { Schulz-Bip. }\end{array}$ & herb & $\begin{array}{l}\text { sesquiterpene lactones }(0.2-1.8 \%) \text {-parthenolid, } \\
\text { eudesmenolide, guajanolide, flavanoids-apigenin, lu- } \\
\text { teolin, chrysoeriols derivatives, essential oil (0.2-0.7\%) }\end{array}$ & 12 \\
\hline
\end{tabular}


N. Wszelaki et al:: Screening of traditional European herbal medicines for acetylcholinesterase and butyrylcholinesterase inhibitory activity, Acta Pharm. 60 (2010) 119-128.

Table III. Continued

\begin{tabular}{|c|c|c|c|}
\hline Plant species & Plant part & Chemical composition & References \\
\hline $\begin{array}{l}\text { Verbena } \\
\text { officinalis L. }\end{array}$ & herb & $\begin{array}{l}\text { iridoid glicosides - verbenalin }(0.15 \%) \text {, hastatoside } \\
(0.08 \%) \text {, dihydrocornine }(0.01 \%) \text { and others, } \\
\text { hydroxycinnamic acid derivatives - verbascoside }(0.8 \\
\%) \text {, isoverbascoside, martynosid, eukovoside, } \\
\text { flavanoids - flavone glycosides, especially luteolin } \\
\text { 7-diglucuronide and apigenin 7-glucuronide, } \\
\text { triterpenes- ursolic acid }\end{array}$ & 11 \\
\hline
\end{tabular}

activity against AChE was reported. Therefore, we performed a TLC- and TLC bioautographic assay to rule out this action.

The TLC bioautographic assay demonstrated that AChE inhibiting activity of Arnica chamissonis was due to compounds which in the TLC bioautographic assay appeared as white spots (Fig. 1). To determine whether the inhibition of AChE activity by arnica extracts was mediated by sesquiterpene lactones, TLC analysis was performed. The compounds that reacted as dark purple-grey spots with anisaldehyde sulfuric acid reagent indicated sesquiterpene lactone derivatives. The location of the white and dark spots on the TLC plate presented in Fig. 1 implicated that the compounds reacting as AChE inhibitors were of sesquiterpene lactones origin. The presented findings have never been reported earlier and we suggest that Arnica chamissonis should be considered for further studies to isolate compounds responsible for the anti-AChE activity.

In the present study, the hexane extract of Rutae herba exhibited moderate AChE and BuChE inhibitory activity with $I C_{50} 34$ and $61 \mu \mathrm{g} \mathrm{mL}^{-1}$, respectively. Adsersen (6) found AChE inhibitory activity of the methanolic extract of Ruta graveolens $(100 \mu \mathrm{g} \mathrm{mL}-1)$, which caused $39 \%$ inhibition; on the other hand, no reports about the activity of Ruta graveolens hexane extract against BuChE inhibition have been published. Compounds present in rue that could be considered to have cholinergic activity included alkaloids and furanocoumarins. It has been previously shown that alkaloids belonging to different groups such as physostigmine, (-)-hupercin A or galanthamine (4) and some furanocoumarines like isoimperatorin, xanthotoxin and marmesin exhibited AChE and BuChE inhibitory effects (7). Kang (7) suggested that coumarin skeleton contained a pyrone moiety, which played an important role in the inhibitory activity against AChE. The presence of coumarines in Ruta could partly explain the anti-AChE activity of the hexane rue extract proven in this study.

The lowest $I C_{50}$ value was obtained with the methanolic extract of Hypericum perforatum herb. The methanolic extract was found to exhibit a weak inhibitory effect against AChE compared to galathamine and physostigmine. It reduced AChE activity to $28 \%$ at a concentration of $400 \mu \mathrm{g} \mathrm{mL}-1$ with $I C_{50}$ of $178 \mu \mathrm{g} \mathrm{mL}^{-1}$. It was previously reported that the ethanolic extract of another Hypericum species, namely Hypericum undulatum, inhibited AChE activity by $69 \%$ at $500 \mu \mathrm{g} \mathrm{mL}^{-1}$ (8). Pharmacological actions of the ethanolic extract of Hypericum perforatum on CNS were well documented in previous reports (9). The inhibiting AChE activity of this extract may belong to these biological actions.

The other tested plant extracts did not exhibit any significant AChE or BuChE inhibitory activity. 
N. Wszelaki et al.: Screening of traditional European herbal medicines for acetylcholinesterase and butyrylcholinesterase inhibitory activity, Acta Pharm. 60 (2010) 119-128.

\section{CONCLUSIONS}

The present investigation has shown that hexane and/or methanolic extracts from the flowers of Arnica chamissonis Less. ssp. foliosa, the herb Ruta graveolens L. and the herb Hypericum perforatum L. could inhibit the activity of AChE or BuChE or both. AChE inhibitory activity of Arnica extracts was among others, due to sequiterpene lactones.

The extracts of arnica, rue and St. John's Wort were proved to have a great potential and should be considered for further studies to identify the constituents responsible for the AChE and BuChE inhibitory activity, which can be eventually utilized in the treatment of AD.

\section{REFERENCES}

1. R. M. Lane, S. G. Potkin and A. Enz, Targeting acetylcholinesterase and butyrylcholinesterase in dementia, Int. J. Neuropsychopharmacol. 9 (2006) 101-124; DOI: 10.1017/S1461145705005833.

2. P. J. Houghton and M. J. Howes, Natural products and derivatives affecting neurotransmission relevant to Alzheimer's and Parkinson's disease, Neurosignals 14 (2005) 2-22; DOI: 10.1159/000085382.

3. G. L. Ellman, D. Courtney, V. Andres and R. M. Featherstone, A new and rapid colorimetric determination of acetylcholinesterase activity, Biochem. Pharmacol. 7 (1961) 88-95; DOI: 10.1016/0006-2952(61)90145-9.

4. A. Marston, J. Kissling and K. Hostettman, A rapid TLC bioautographic method for the detection of acetylcholinesterase and butyrylcholinesterase inhibitors in plants, Phytochem. Anal. 13 (2002) 51-54; DOI: 10.1002/pca.623.

5. N. Perry, G. Court, N. Bidet, J. Court and E. Perry, European herbs with cholinergic activities: potential in dementia therapy, Int. J. Geriatr. Psychiatr. 11 (1996) 1063-1069; DOI: 10.1002/(SICI) 1099-1166(199612)11:12<1063::AID-GPS532>3.0.CO;2-1.

6. A. Adsersen, B. Gauguin, L. Gudiksen and A. K. Jäger, Screening of plants used in Danish folk medicine to treat memory dysfunction for acetylcholinesterase inhibitory activity, J. Ethnopharmacol. 104 (2006) 418-422; DOI: 10.1016/j.jep.2005.09.032.

7. S. Y. Kang, K. Y. Lee, S. H. Sung, M. J. Park and Y. C. Kim, Coumarins isolated from Angelica gigas inhibit acetylcholinesterase: structure-activity relationships, J. Nat. Prod. 64 (2001) 683-685; DOI: $10.1021 / \mathrm{np} 000441 \mathrm{w}$.

8. A. Ferreira, C. Proenca, M. L. Serralheiro and M. E. Araujo, The in vitro screening for acetylcholinesterase inhibition and antioxidant activity of medicinal plants from Portugal, J. Ethnopharmacol. 108 (2006) 31-37; DOI: 10.1016/j.jep.2006.04.010.

9. T. Mennini and M. Gobbi, The antidepressant mechanism of Hypericum perforatum, Life Sci. 9 (2004) 1021-1027; DOI: 10.1016/j.lfs.2004.04.005.

10. G. Romussi, G. Ciarallo, G. Falsone and C. Schneider, Constituents of Boraginaceae. - Triterpene saponins from Anchusa officinalis L., Liebigs Ann. Chem. 12 (1979); DOI: 10.1002/jlac.197919791213.

11. P. Bradley, British Herbal Compendium, Vol. 2, $1^{\text {st }}$ ed., British Herbal Medicine Association, Bournemouth 2006.

12. M. Wichtl, Herbal Drugs and Phytopharmaceuticals, $5^{\text {th }}$ ed., Medpharm Scientific Publishers, Stuttgart 2009.

13. H. U. Wolf, Hager's Textbook of Pharmaceutical Practice, Vol. 5, $5^{\text {th }}$ ed., Springer Heidelberg 1993, p. 223. 
N. Wszelaki et al.: Screening of traditional European herbal medicines for acetylcholinesterase and butyrylcholinesterase inhibitory activity, Acta Pharm. 60 (2010) 119-128.

14. E. Teuscher, M. Melzig and U. Lindequist, Biogenic Drugs, $6^{\text {th }}$ ed., Medpharm Scientific Publishers, Stuttgart 2004, p. 528.

$S A \check{Z} E T A K$

\section{Pretraživanje tradicionalnih europskih ljekovitih biljaka na inhibiciju acetilkolinesteraze $\mathrm{i}$ butirilkolinesteraze}

NATALIA WSZELAKI, AGNIESZKA KUCIUN i ANNA KAROLINA KISS

Inhibitori acetilkolinesteraze (AChE) povećavaju kolinergičku transmisiju u mozgu, pa se koriste za simptomatsko liječenje Alzheimerove bolesti (AD). S druge strane, inhibitori butirilkolinesteraze (BuChE) značajno povećavaju ekstracelularnu količinu $\mathrm{AChE}$ u mozgu, a da pri tome ne uzrokuju snažne nuspojave ni u središnjem ni i perifernom živčanom sustavu. Galantamin, jedan od odobrenih AChE inhibitora, alkaloid iz lukovica narcisa, pokazuje da su biljke značajni izvor novih potencijalnih AChE- i BuChEinhibitora. U ovom radu, ispitivan je učinak dvanaest biljaka koje se koriste u tradicionalnoj europskoj medicini na različite poremećaje središnjeg živčanog sustava i na poboljšanje pamćenja. Pomoću Ellmanove kolorimetrijske metode praćen je inhibitorni učinak metanolnih i heksanskih ekstrakata tih biljaka na AChE i BuChE. Najjači inhibitorni učinak pokazali su heksanski ekstrakti cvjetova Arnica chamissonis Less. susb. foliosa i nadzemnih dijelova Ruta graveolens L. u koncentraciji od $400 \mu \mathrm{g} \mathrm{mL}^{-1}$. Međutim, metanolni ekstrakti crjetova Arnica chamissonis Less. susb. foliosa i nadzemnih dijelova Hypericum perforatum L. u istim koncentracijama pokazuju selektivnu inhibiciju samo na AChE. Ostali ekstrakti bili su nedjelotvorni. Rezultati ukazuju na potrebu daljnjih ispitivanja ekstrakata arnike, rute i gospine trave da se utvrdi koji su sastojci ekstrakata odgovorni za inhibiciju AChE i BuChE.

Ključne riječi: inhibicija acetilkolinesteraze, inhibicija butirilkolinesteraze, tradicionalna medicina

Institute of Pharmacy, Free University of Berlin, D-14195 Berlin, Germany

Department of Pharmacognosy and Molecular Basis of Phytotherapy, Faculty of Pharmacy, Medical University of Warsaw, 02-098 Warsaw, Poland 